\title{
OPINION
}

\section{Trends in global semen parameter values}

\author{
Harry Fisch and Stephen R Braun
}

Asian Journal of Andrology (2013) 15, 169-173; doi:10.1038/aja.2012.143; published online 7 January 2013

\begin{abstract}
A llegations for a worldwide decline in A semen parameter values have not withstood scientific scrutiny. Methodological flaws in an influential 1992 paper are summarized here, and studies that have been published since 1992 are reviewed. Of the 35 major studies of time trends in semen quality reviewed here, eight (a total of 18109 men) suggest a decline in semen quality; 21 (112 386 men) show either no change or an increase in semen quality; and six (26 007 men) show ambiguous or conflicting results. The cause (or causes) of the geographical and temporal variations in semen parameter values reported by these diverse studies deserve further investigation.

This paper critically examines two related scientific assertions: that there have been worldwide declines in semen quality in recent decades and that these declines are related to environmental exposure to minute levels of 'endocrine disruptors' (chemicals that exhibit some degree of estrogen-like activity in the body). The data supporting these assertions will be demonstrated to be weak, at best. Reported declines in semen parameter values are likely to be either highly local phenomena with an unknown etiology or the result of methodological errors arising from attempts to observe highly variable physical attributes (semen characteristics) with relatively lowresolution tools (retrospective analysis of nonrandomized study populations).
\end{abstract}

\section{METHODOLOGICAL CHALLENGES}

For many reasons, semen may be the most poorly understood bodily fluid, in terms of the distribution of its normal values in the general population. One problem is the relative difficulty of obtaining human semen for

Departments of Urology and Reproductive Medicine Weill Cornell Medical College, New York Presbyterian Hospital, New York, NY 10028, USA

Correspondence: Dr H Fisch (harryfisch@aol.com) Received: 23 October 2012; Revised: 5 November 2012; Accepted: 13 November 2012; Published online: 7 January 2013 scientific analysis. The fact that semen is most readily obtained by masturbation poses significant logistical barriers to objective, randomized, longitudinal studies of semen parameters in community-dwelling men. For example, participation rates in the few studies that have attempted to assess semen quality in non-infertile men have typically been $<20 \%)^{1,2}$ Although it is possible, in principle, to conduct large-scale populationbased trials, the procedural issues involved are challenging, which is likely the reason that such trials have not yet been conducted. Instead, research to date on semen quality has relied on populations of men who have provided semen samples for sperm donation, infertility evaluation, prevasectomy evaluation, or for other specific reasons. Each of these populations presents a possible selection bias and none represent a random sample of the population at large. For example, semen donors may have been screened for problems known to affect fertility, or they may have been selected precisely because a prior semen analysis indicated robust fertility. Male donors in cases of in vitro fertilization or other attempts to overcome infertility issues, on the other hand, are more likely to have low fertility, regardless of the fertility status of their partner. It is, therefore, fundamentally difficult at present to determine 'normal' semen parameters for communitydwelling populations of men.

In addition, semen attributes such as sperm count, semen volume and sperm morphology vary widely between individuals as well as within individuals over time. Longer periods of time since the previous ejaculation (abstinence time), for example, are associated with higher sperm counts, higher semen volumes and a higher percentage of sperm displaying abnormal morphology. Other sources of variability include: scrotal temperature, ${ }^{3}$ season of the year, ${ }^{4}$ smoking status, ${ }^{5}$ marijuana use ${ }^{6}$ and geographic region. ${ }^{7}$ Although some studies of semen parameter values have attempted to control for some of these variables, many have not, which seriously compromises the conclusions that can be drawn from such studies.

\section{CRITICAL ANALYSIS OF AN INFLUENTIAL PAPER}

In 1992, Carlsen et al. ${ }^{8}$ published a metaanalysis of 61 previous studies of semen parameters and reported a nearly 50\% drop in sperm concentrations, from $113 \times 10^{6}$ per $\mathrm{ml}$ in 1940 to only $66 \times 10^{6}$ sperm per $\mathrm{ml}$ in 1990 , and raised the question of whether this 'decline' might be due to exposure to compounds with estrogen-like activity. Although the paper generated a great deal of media attention, it has been repeatedly criticized in the scientific community for its many methodological flaws. ${ }^{9-13}$ These flaws include: high cross-study variability in the methods and protocols used for sperm collection and measurement; lack of control for period of abstinence, cigarette smoking or recreational drug use; failure to include some studies reporting no decline in semen parameters; and failure to account for geographic variation between studies.

The pronounced geographic variation in semen quality in particular, is a source of serious error. All of the studies included in the meta-analysis from before 1970 were from the United States, and $80 \%$ of these were from New York State, where sperm counts (then and now) are higher than average. After 1970, only three studies were from the United States, and many were from third-world countries where sperm counts were lower than average. If the Carlsen data are reanalyzed to account for this geographic variation, no decline in sperm counts is found (Figure 1). ${ }^{7}$

Another potential weakness of the Carlsen study involves the use of an inappropriate linear regression model in the 


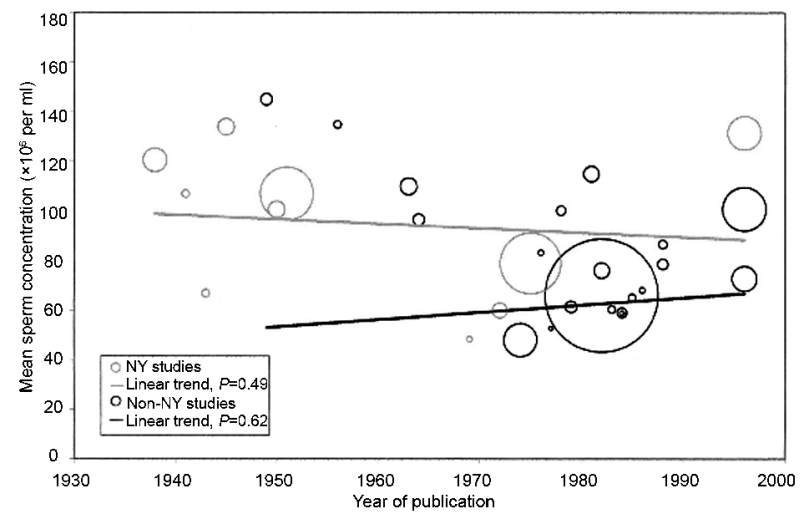

Figure 1 Reanalysis of data from Carlsen et al. ${ }^{8}$ showing no decline in sperm concentrations (black regression line) when data from New York are excluded. Bubble size corresponds to number of men in study. ${ }^{9}$

statistical analysis. ${ }^{14}$ Because the data distribution was highly nonuniform, quadratic or spline regression models are more appropriate analytical tools. When these tools are applied to the Carlsen data, mean sperm concentrations have actually increased since $1940 .^{12}$

In the two decades since publication of Carlsen's paper, at least 35 major studies of time trends in semen parameters have been published. Eight (on a total of 18109 men) suggest a decline in semen parameter values (Table 1); 21 (on a total of 112386 men) show either no change or an increase in semen quality (Table 2); and six (on a total of 26007 men) show ambiguous or conflicting results (Table 3). (Studies that reanalyzed existing data or that were critiques in general ways of some of the methodological issues involved in the debate over alleged changes in semen parameters were not included in this review.) As with previous studies, all of these investigations rely on populations of men who are not necessarily representative of the general male population.

The evidence provided by these studies refutes the simplistic notion of a worldwide decline in semen parameters, though, clearly, they also demonstrate that semen parameter values vary dramatically both geographically and temporally. These variations may arise from numerous causative factors including: differences in lab techniques and analysis between regions; differences in sexual behavior that alter mean abstinence times between regions; genetic variations between populations; variation in lifestyle factors such as obesity or recreational drug use; or variations in in utero exposure to mutagenic compounds or environmental pollutants. The wide geographic variations in semen parameter values cannot yet be adequately explained; however, they must be adequately controlled for in any metaanalyses or other attempts to draw broad conclusions about worldwide trends.

To date, however, the data supporting a role for 'endocrine disruptors' in the alleged 'decline' in semen parameters is weak. ${ }^{15}$ Some, but not all, studies, for example, have found no association between variations in semen quality and location in rural vs. urban areas, or between areas with known high levels of air pollution and those with less pollution. ${ }^{16}$ Moreover, a potential causal relationship between semen quality and 'endocrine disruptors' cannot be investigated by studies of semen parameters alone. A recent review of epidemiological studies of

Table 1 Studies showing a decline in semen parameter values (total sample size $=18109$ )

\begin{tabular}{|c|c|c|c|c|c|}
\hline Year & First author & $\begin{array}{l}\text { Sample } \\
\text { size }\end{array}$ & Study period & Location & Major findings \\
\hline 1995 & Auger $^{19}$ & 1351 & 1973-1992 & France & $\begin{array}{l}\text { 1. Mean volume: no change. } \\
\text { 2. Mean sperm concentration declined } 2.1 \% \text { per year from } 89 \text { million per ml to } 60 \text { million } \\
\text { per } \mathrm{ml} \text {. } \\
\text { 3. Percent motile sperm decreased } 0.6 \% \text { per year. } \\
\text { 4. Percent normal sperm decreased by } 0.5 \% \text { per year. }\end{array}$ \\
\hline 1996 & Irvine ${ }^{20}$ & 577 & 1984-1995 & Scotland & $\begin{array}{l}\text { 1. Sperm concentration fell from } 98 \text { million per } \mathrm{ml} \text { in older cohort to } 78 \text { million per ml among } \\
\text { donors born after } 1970 \text {. } \\
\text { 2. Total motile sperm count fell from } 169 \text { million to } 129 \text { million. } \\
\text { 3. Concentration declined } 2.1 \% \text { per year. } \\
\text { 4. Motility increased } 0.18 \% \text { per year. }\end{array}$ \\
\hline 1996 & Adamopoulos $^{21}$ & 2385 & 1977-1993 & Greece & $\begin{array}{l}\text { 1. Total sperm count declined from } 154.3 \text { million to } 130.1 \text { million. } \\
\text { 2. No significant drop in semen volume. }\end{array}$ \\
\hline 1998 & Bonde $^{22}$ & 1196 & 1986-1995 & Denmark & $\begin{array}{l}\text { 1. Median sperm concentration dropped from } 63 \text { million per ml in men born 1937-1949 to } \\
52 \text { million per } \mathrm{ml} \text { in men born } 1970 \text { and later. } \\
\text { 2. Median total sperm count dropped from } 206 \text { million and } 117 \text { million respectively. }\end{array}$ \\
\hline 1999 & Bilotta $^{23}$ & 1068 & 1981-1995 & Italy & $\begin{array}{l}\text { 1. } 31 \% \text { decline in sperm concentration over the study period. } \\
\text { 2. } 8 \% \text { decline in motility. } \\
\text { 3. } 9 \% \text { decline in sperm with 'typical morphology'. }\end{array}$ \\
\hline 2003 & Almagor $^{24}$ & 2638 & 1990-2000 & Israel & $\begin{array}{l}\text { 1. Sperm count declined by } 5.2 \text { million each year. } \\
\text { 2. Motility declined by } 0.5 \% \text { per year. }\end{array}$ \\
\hline 2005 & Lackner $^{25}$ & 7780 & 1986-2003 & Austria & $\begin{array}{l}\text { 1. Study population was infertile men } \\
\text { 2. Decline in sperm concentration from } 27.75 \text { million per ml in } 1986 \text { to } 4.60 \text { million per ml } \\
\text { in } 2003 \text {. }\end{array}$ \\
\hline 2012 & Splingart ${ }^{26}$ & 1114 & 1976-2009 & France & $\begin{array}{l}\text { 1. No decline in semen volume. } \\
\text { 2. Decrease in total sperm count from } 443 \text { million in } 1976 \text { to } 300 \text { million in } 2009 \text {. } \\
\text { 3. Motility declines from } 64 \% \text { to } 49 \% \text {. } \\
\text { 4. Decline in percent of 'normal forms' from } 67 \% \text { to } 26 \% \text {. }\end{array}$ \\
\hline
\end{tabular}


Table 2 Studies finding no decline or an increase in sperm count (total sample size=112 386)

\begin{tabular}{|c|c|c|c|c|c|}
\hline Year & First author & Sample size & Study period & Location & Major findings \\
\hline 1996 & Bujan $^{27}$ & 302 & 1977-1992 & France & 1. Sperm counts remained constant after adjustment for age of donors. \\
\hline 1996 & Paulsen $^{28}$ & 510 & 1972-1993 & United States & $\begin{array}{l}\text { 1. No decreases in sperm count, volume, sperm concentration or normal } \\
\text { morphology. }\end{array}$ \\
\hline 1996 & Vierula $^{29}$ & 5481 & 1967-1994 & Finland & $\begin{array}{l}\text { 1. Mean sperm concentration unchanged across the study period. } \\
\text { 2. Total sperm count and sperm density unchanged. } \\
\text { 3. No trends up or down in birth cohort data. }\end{array}$ \\
\hline 1996 & Fisch $^{7}$ & 1283 & 1970-1994 & United States & $\begin{array}{l}\text { 1. Sperm concentration increased from mean of } 77 \text { million per } \mathrm{ml} \text { to } 89 \text { million per } \\
\mathrm{ml} \text {. } \\
\text { 2. Motility constant, though mean volume decreased slightly. }\end{array}$ \\
\hline 1997 & Berling $^{30}$ & 718 & 1985-1995 & Sweden & $\begin{array}{l}\text { 1. Sperm concentration rose from } 46 \text { million per } \mathrm{ml} \text { in } 1985 \text { to } 64 \text { million per } \mathrm{ml} \text { in } \\
1995 \text {. } \\
\text { 2. Sperm with normal morphology rose from } 58 \% \text { to } 66.4 \% \text {. }\end{array}$ \\
\hline 1997 & Benshushan $^{31}$ & 188 & 1980-1995 & Israel & $\begin{array}{l}\text { 1. Volume increased } 5.1 \% \text { per year. } \\
\text { 2. Total motile sperm count rose } 7.7 \% \text { per year. } \\
\text { 3. Motility increased } 0.27 \% \text { per year. }\end{array}$ \\
\hline 1997 & Handelsman ${ }^{32}$ & 689 & 1980-1995 & Australia & $\begin{array}{l}\text { 1. Overall mean for period was } 69 \text { million per ml. } \\
\text { 2. No significant change in semen volume, total sperm count, or sperm } \\
\text { concentration over study period. }\end{array}$ \\
\hline 1997 & Rasmussen $^{33}$ & 1055 & 1950-1970 & Denmark & $\begin{array}{l}\text { 1. No decline in semen parameters observed over study period. } \\
\text { 2. Comparison of four birth cohorts revealed no association with changes in sperm } \\
\text { quality. }\end{array}$ \\
\hline 1998 & Emanuel $^{34}$ & 374 & 1971-1994 & United States & $\begin{array}{l}\text { 1. No significant differences between mean or median sperm counts between } \\
\text { subjects in modern group compared to } 1000 \text { subjects in MacLeod and Gold's } \\
1951 \text { study. }\end{array}$ \\
\hline 1998 & Younglai $^{35}$ & 48968 & 1984-1996 & Canada & $\begin{array}{l}\text { 1. Linear regression analysis of the means of each of } 11 \text { centers studied over study } \\
\text { period showed no significant trend. }\end{array}$ \\
\hline 1999 & Andolz ${ }^{36}$ & 20411 & 1960-1996 & Spain & $\begin{array}{l}\text { 1. } 0.04 \% \text { increase in sperm count per year. } \\
\text { 2. } 0.4 \% \text { increase in motility. }\end{array}$ \\
\hline 1999 & Gyllenborg ${ }^{4}$ & 1927 & 1977-1995 & Denmark & $\begin{array}{l}\text { 1. Increase in mean sperm concentration from } 53 \text { million per ml to } 72.7 \text { million per } \\
\mathrm{ml} \text {. } \\
\text { 2. Increase in total sperm count from } 166 \text { million to } 227 \text { million. }\end{array}$ \\
\hline 1999 & Zorn $^{37}$ & 2343 & 1983-1996 & Slovenia & $\begin{array}{l}\text { 1. Volume, concentration and total sperm count did not change in study period. } \\
\text { 2. Sperm concentration analyzed by birth cohort showed a decline from } 1950 \text { to } \\
\text { 1960, then an increase after } 1960 \text {. }\end{array}$ \\
\hline 2000 & Acacio $^{38}$ & 1347 & 1951-1997 & United States & $\begin{array}{l}\text { 1. No decline in sperm concentration found when compared to MacLeod data from } \\
1951 \text { and } 1979 \text {. }\end{array}$ \\
\hline 2000 & $\mathrm{Seo}^{39}$ & 22249 & 1989-1998 & Korea & $\begin{array}{l}\text { 1. Mean sperm concentration was } 60.5 \text { million per ml. } \\
\text { 2. No change in concentration, volume or motility in study period. }\end{array}$ \\
\hline 2001 & Itoh $^{40}$ & 711 & 1975-1998 & Japan & $\begin{array}{l}\text { 1. Volume was unchanged. } \\
\text { 2. Sperm concentration was } 70.9 \text { million per } \mathrm{ml} \text { in early study compared to } 79.6 \\
\text { million per } \mathrm{ml} \text { in later. }\end{array}$ \\
\hline 2002 & Costello $^{41}$ & 448 & 1983-2001 & Australia & $\begin{array}{l}\text { 1. No significant change in sperm count or ejaculate volume. } \\
\text { 2. Increase in sperm motility. }\end{array}$ \\
\hline 2003 & Marimuthu ${ }^{42}$ & 1176 & 1990-2000 & India & $\begin{array}{l}\text { 1. No significant decline in sperm counts was observed in any year during the entire } \\
\text { study period. }\end{array}$ \\
\hline 2006 & $\mathrm{~Pa}{ }^{43}$ & 368 & 1993-2005 & India & $\begin{array}{l}\text { 1. Mean sperm concentration and semen volume } \\
\text { have not decreased in Indian men over the last few decades. }\end{array}$ \\
\hline 2011 & Axelsson ${ }^{44}$ & 511 & $\begin{array}{l}\text { 2000/2001- } \\
2008-2010\end{array}$ & Sweden & $\begin{array}{l}\text { 1. A nonsignificant rise in sperm concentration, from } 78 \text { million per } \mathrm{ml} \text { to } 82 \text { million } \\
\text { per } \mathrm{ml} \text {. } \\
\text { 2. Nonsignificant increase in total sperm counts from } 220 \text { million per } \mathrm{ml} \text { vs. } 250 \\
\text { million per } \mathrm{ml} \text {. }\end{array}$ \\
\hline 2012 & Elia $^{45}$ & 1327 & 1992-2012 & Italy & $\begin{array}{l}\text { 1. Sperm concentration, volume and progressive motility significantly higher in } 2010 \\
\text { group than } 1992 \text { group. }\end{array}$ \\
\hline
\end{tabular}

changes in semen parameter values and exposure to endocrine disrupters concluded that convincing human evidence that such exposure has an impact on male fertility is still lacking. ${ }^{17}$

It is worth nothing that, in contrast to the wide variations in results of studies of semen parameter values, studies of temporal trends in testosterone levels have been more uniform. Data from randomized, adequately sized populations of community-dwelling men show a clear and consistent decline in mean testosterone levels in recent decades. ${ }^{18}$ Whether such declines are related to the declines in semen quality reported in a minority of studies reviewed here remains to be scientifically explored.

\section{CONCLUSION}

The allegations for a worldwide decline in semen parameter values presented by Carlsen et al. ${ }^{8}$ in 1992 have not withstood scientific scrutiny. This paper, and others, 
Table 3 Studies presenting ambiguous results (total sample size $=26$ 007)

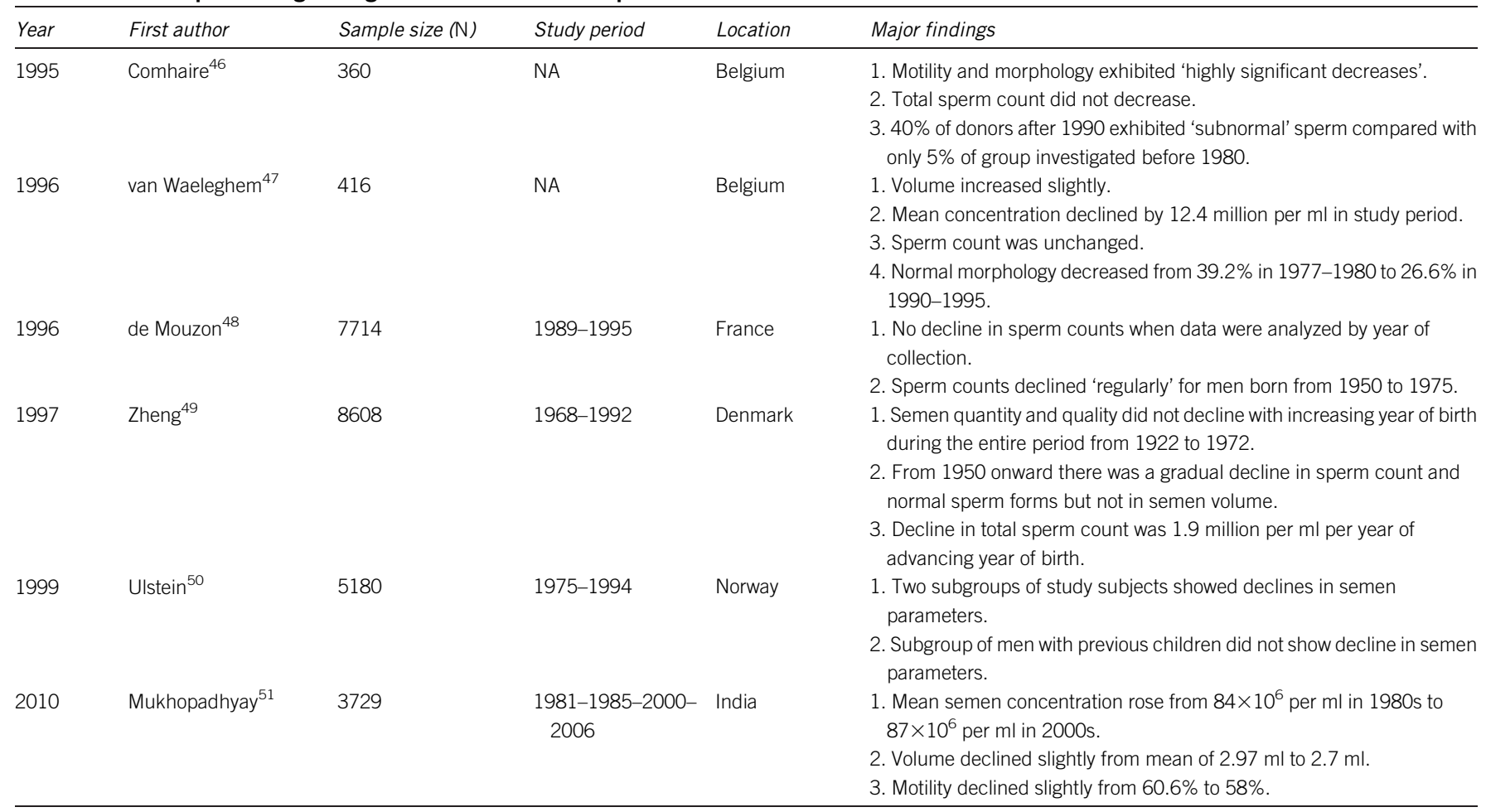

Abbreviation: NA, not applicable.

have detailed the methodological flaws in the Carlsen paper that warrant its exclusion from future reviews of the data pertaining to variations in semen quality over time. In the two decades since publication of Carlsen's paper, at least 35 major studies of time trends in semen parameters have been published. Eight (on a total of 18109 men) suggest a decline in semen parameters; 21 (on 112386 men) show either no change or an increase in semen parameters; and six (on 26007 men) show ambiguous or conflicting results. The cause (or causes) of the geographical and temporal variations in semen parameters reported by these diverse studies deserve further investigation.

\section{COMPETING FINANCIAL INTERESTS}

The authors declare no competing financial interests in relation to this paper.

1 Jensen TK, Jørgensen N, Punab M, Haugen TB, Suominen $\mathrm{J}$ et al. Association of in utero exposure to maternal smoking with reduced semen quality and testis size in adulthood: a cross-sectional study of 1770 young men from the general population in five European countries. Am J Epidemiol 2004; 159: 49-58.

2 Cohn BA, Overstreet JW, Fogel RJ, Brazil CK, Baird DD et al. Epidemiologic studies of human semen quality: considerations for study design. Am J Epidemiol 2002; 155: 664-71.
3 Zorgniotti AW, Macleod J. Studies in temperature, human semen quality, and varicocele. Fertil Steril 1973; 24: 854-63.

4 Gyllenborg J, Skakkebaek NE, Nielsen NC, Keiding N, Giwercman A. Secular and seasonal changes in semen quality among young Danish men: a statistical analysis of semen samples from 1927 donor candidates during 1977-1995. Int J Androl 1999; 22: 28-36.

5 Vine MF, Margolin BH, Morrison HI, Hulka BS. Cigarette smoking and sperm density: a metaanalysis. Fertil Steril 1994; 61: 35-43.

6 Nahas GG, Frick HC, Lattimer JK, Latour C, Harvey D. Pharmacokinetics of $\mathrm{THC}$ in brain and testis, male gametotoxicity and premature apoptosis of spermatozoa. Hum Psychopharmacol 2002; 17: 103-13.

7 Fisch H, Goluboff ET, Olson JH, Feldshuh J, Broder SJ et al. Semen analyses in 1,283 men from the United States over a 25-year period: no decline in quality. Fertil Steril 1996; 65: 1009-14.

8 Carlsen E, Giwercman A, Keiding N, Skakkebaek NE. Evidence for decreasing quality of semen during past 50 years. BMJ 1992; 305: 609-13.

9 Saidi JA, Chang DT, Goluboff ET, Bagiella E, Olsen G et al. Declining sperm counts in the United States? A critical review. J Urol 1999; 161: 460-2.

10 Farrow S. Falling sperm quality: fact or fiction? BMJ 1994; 309: 1-2.

11 Becker S, Berhane K. A meta-analysis of 61 sperm count studies revisited. Fertil Steril 1997; 67: 1103-8.

12 Emanuel ER, Goluboff ET, Fisch H. MacLeod revisited: sperm count distributions in 374 fertile men from 1971 to 1994. Urology 1998; 51: 868.

13 Fisch H, Goluboff ET. Geographic variations in sperm counts: a potential cause of bias in studies of semen quality. Fertil Steril 1996; 65: 1044-6.

14 Olsen GW, Bodner KM, Ramlow JM, Ross CE, Lipshultz LI. Have sperm counts been reduced 50 percent in 50 years? A statistical model revisited. Fertil Steril 1995; 63: 887-93.
15 Safe SH. Endocrine disruptors and human health-is there a problem? An update. Environ Health Perspect 2000; 108: 487-93.

16 Swan SH, Brazil C, Drobnis EZ, Liu F, Kruse RL et al. Geographic differences in semen quality of fertile U.S. males. Environ Health Perspect 2003; 111: 414-20.

17 Giwercman A. Estrogens and phytoestrogens in male infertility. Curr Opin Urol 2011; 21: 519-26.

18 Travison TG, Araujo AB, O'Donnell AB, Kupelian V, McKinlay JB. A population-level decline in serum testosterone levels in American men. J Clin Endocrinol Metab 2007; 92: 196-202.

19 Auger J, Kunstmann JM, Czyglik F, Jouannet P. Decline in semen quality among fertile men in Paris during the past 20 years. N Engl J Med 1995; 332: 281-5.

20 Irvine DS, Aitken RJ. Seminal fluid analysis and sperm function testing. Endocrinol Metab Clin North Am 1994; 23: 725-48.

21 Adamopoulos DA, Pappa A, Nicopoulou S, Andreou E, Karamertzanis $\mathrm{M}$ et al. Seminal volume and total sperm number trends in men attending subfertility clinics in the greater Athens area during the period 1977-1993. Hum Reprod 1996; 11: 1936-41.

22 Bonde JP, Kold Jensen T, Brixen Larsen S, Abell A, Scheike T et al. Year of birth and sperm count in 10 Danish occupational studies. Scand J Work Environ Health 1998; 24: 407-13.

23 Bilotta P, Guglielmo R, Steffè M. [Analysis of decline in seminal fluid in the Italian population during the past 15 years]. Minerva Ginecol 1999; 51: 223-31.

24 Almagor M, Ivnitzki I, Yaffe H, Baras M. Changes in semen quality in Jerusalem between 1990 and 2000: a cross-sectional and longitudinal study. Arch Androl 2003; 49: 139-44.

25 Lackner J, Schatzl G, Waldhör T, Resch K, Kratzik C et al. Constant decline in sperm concentration in infertile males in an urban population: experience over 18 years. Fertil Steril 2005; 84: 1657-61.

26 Splingart C, Frapsauce C, Veau S, Barthélémy C, Royère $D$ et al. Semen variation in a population of 
fertile donors: evaluation in a French centre over a 34 year period. Int J Androl 2012; 35: 467-74.

27 Bujan L, Mansat A, Pontonnier F, Mieusset R. Time series analysis of sperm concentration in fertile men in Toulouse, France between 1977 and 1992. BMJ 1996; 312: 471-2.

28 Paulsen CA, Berman NG, Wang C. Data from men in greater Seattle area reveals no downward trend in semen quality: further evidence that deterioration of semen quality is not geographically uniform. Fertil Steril 1996; 65: 1015-20.

29 Vierula M, Niemi M, Keiski A, Saaranen M, Saarikoski $S$ et al. High and unchanged sperm counts of Finnish men. Int J Androl 1996; 19: 11-7.

30 Berling S, Wölner-Hanssen P. No evidence of deteriorating semen quality among men in infertile relationships during the last decade: a study of males from Southern Sweden. Hum Reprod 1997, 12: 1002-5.

31 Benshushan A, Shoshani O, Paltiel O, Schenker JG, Lewin A. Is there really a decrease in sperm parameters among healthy young men? A survey of sperm donations during 15 years. J Assist Reprod Genet 1997; 14: 347-53.

32 Handelsman DJ. Sperm output of healthy men in Australia: magnitude of bias due to self-selected volunteers. Hum Reprod 1997; 12: 2701-5.

33 Rasmussen PE, Erb K, Westergaard LG, Laursen SB. No evidence for decreasing semen quality in four birth cohorts of 1,055 Danish men born between 1950 and 1970. Fertil Steril 1997; 68: 1059-64.

34 Emanuel ER, Goluboff ET, Fisch H. MacLeod revisited: sperm count distributions in 374 fertile men from 1971 to 1994 . Urology 1998; 51: 86-8.
35 Younglai EV, Collins JA, Foster WG. Canadian semen quality: an analysis of sperm density among eleven academic fertility centers. Fertil Steril 1998; 70: 76-80.

36 Andolz P, Bielsa MA, Vila J. Evolution of semen quality in North-eastern Spain: a study in 22,759 infertile men over a 36 year period. Hum Reprod 1999; 14: 731-5.

37 Zorn B, Virant-Klun I, Verdenik I, Meden-Vrtovec H. Semen quality changes among 2343 healthy Slovenian men included in an IVF-ET programme from 1983 to 1996. Int J Androl 1999; 22: 178-83.

38 Acacio BD, Gottfried T, Israel R, Sokol RZ. Evaluation of a large cohort of men presenting for a screening semen analysis. Fertil Steril 2000; 73: 595-7.

39 Seo JT, Rha KH, Park YS, Lee MS. Semen quality over a 10-year period in 22,249 men in Korea. Int J Androl 2000; 23: 194-8.

40 Itoh N, Kayama F, Tatsuki TJ, Tsukamoto T. Have sperm counts deteriorated over the past 20 years in healthy, young Japanese men? Results from the Sapporo area. J Androl 2001; 22: 40-4.

41 Costello MF, Sjoblom P, Haddad Y, Steigrad SJ, Bosch EG. No decline in semen quality among potential sperm donors in Sydney, Australia, between 1983 and 2001. J Assist Reprod Genet 2002; 19: 284-90.

42 Marimuthu P, Kapilashrami MC, Misro MM, Singh G. Evaluation of trend in semen analysis for 11 years in subjects attending a fertility clinic in India. Asian $J$ Androl 2003; 5: 221-5.

43 Pal PC, Rajalakshmi M, Manocha M, Sharma RS, Mittal S et al. Semen quality and sperm functional parameters in fertile Indian men. Andrologia 2006; 38: 20-5.

44 Axelsson J, Rylander L, Rignell-Hydbom A, Giwercman A. No secular trend over the last decade in sperm counts among Swedish men from the general population. Hum Reprod 2011; 26: 1012-6.

45 Elia J, Imbrogno N, Delfino M, Rossi T, Mazzilli R et al. Comparative study of seminal parameters between samples collected in 1992 and samples collected in 2010. Arch Ital Urol Androl 2012; 84: 26-31.

46 Comhaire F, van Waeleghem K, de Clercq $N$, Vermeulen L, Schoonjans F. Statement on the general reduction in sperm quality. Int $J$ Androl 1995; 18 Suppl 2: 1-2.

47 van Waeleghem $K$, de Clercq $N$, Vermeulen $L$, Schoonjans F, Comhaire F. Deterioration of sperm quality in young healthy Belgian men. Hum Reprod 1996; 11: 325-9.

48 de Mouzon J, Thonneau P, Spira A, Multigner L. Declining sperm count. Semen quality has declined among men born in France since 1950. BMJ 1996; 313: 43.

49 Zheng Y, Bonde JP, Ernst E, Mortensen JT, Egense J. Is semen quality related to the year of birth among Danish infertility clients? Int J Epidemiol 1997; 26: 1289-97.

50 Ulstein M, Irgens A, Irgens LM. Secular trends in sperm variables for groups of men in fertile and infertile couples. Acta Obstet Gynecol Scand 1999, 78: 332-5.

51 Mukhopadhyay D, Varghese AC, Pal M, Banerjee SK Bhattacharyya AK et al. Semen quality and agespecific changes: a study between two decades on 3,729 male partners of couples with normal sperm count and attending an andrology laboratory for infertility-related problems in an Indian city. Fertil Steril 2010; 93: 2247-54. 